\title{
Effect of UV-C radiation and vapor released from a water hyacinth root absorbent containing bergamot oil to control mold on storage of brown rice
}

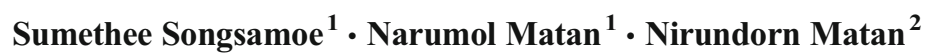

Revised: 18 November 2015 / Accepted: 14 December 2015/Published online: 5 January 2016

(C) Association of Food Scientists \& Technologists (India) 2016

\begin{abstract}
The aims of this study were to develop absorbent material from a water hyacinth root containing bergamot oil and to improve its antifungal activity by using ultraviolet $\mathrm{C}$ (UV-C) against the growth of A. flavus on the brown rice. Process optimization was studied by the immersion of a water hyacinth root into a water and bergamot oil $(300,500$ and $700 \mu \mathrm{ml}^{-1}$ ). The root (absorbent material) was dried at 50, 70 , and $90^{\circ} \mathrm{C}$ for $10 \mathrm{~min}$. Then, ultraviolet C (UV-C) was used for enhancing the antifungal activity of bergamot oil for 10 , 15 , and $20 \mathrm{~min}$. The shelf-life of the brown rice with the absorbent after incubation at $25^{\circ} \mathrm{C}$ with $100 \% \mathrm{RH}$ for 12 weeks was also investigated. A microscope and a Fourier transform infrared spectroscopy (FTIR) were used to find out possible mode of action. Results indicated that the absorbent material produced from the water hyacinth root containing bergamot oil at $500 \mu \mathrm{ml}^{-1}$ in the water solution, dried at $70{ }^{\circ} \mathrm{C}$ and $\mathrm{UV}$ for $15 \mathrm{~min}$ showed the highest antifungal activity in a vapor phase against $A$. flavus on the brown rice. A microscopy investigation confirmed that the water hyacinth root could absorb bergamot oil from an outside water solution into root cells. Limonene in vapor phase was shown to be a stronger inhibitor than essential oil after UV-C radiation and should be the key factor in boosting bergamot oil antifungal activity. A vapor phase of bergamot oil could be released and inhibit natural mold on the surface of the brown rice for up to
\end{abstract}

Narumol Matan

nnarumol@yahoo.com; nnarumol@wu.ac.th

1 Food Technology, School of Agricultural Technology, Walailak University, Nakhon Si Thammarat, Thailand 80161

2 Materials Science and Engineering, School of Engineering and Resources, Walailak University, Nakhon Si Thammarat, Thailand 80161
12 weeks; without the absorbent, mold covered the brown rice in only 4 weeks.

Keywords Absorbent material $\cdot$ Water hyacinth root . Bergamot oil $\cdot$ Shelf-life $\cdot$ Brown rice

\section{Introduction}

The long term storage of brown rice is very significant. Brown rice is one of the most important grains in the world. It is normally contaminated by molds such as A. flavus during storage (Choi et al. 2015). In ecosystems of grain storage, temperature, moisture content and gas composition are significant factors for mold growth. While storage technology could control and reduce mold growth, using an expensive computerized system to control storage room temperatures and high $\mathrm{CO}_{2}$ concentration $(\sim 100 \%)$ is required (Carvalho et al. 2012). So finding an alternative technology to decrease mold growth after post harvest is of current interest.

The water hyacinth (Eichhornia crassipes (Mart.) Solms) can be found in garden ponds around tropical and subtropical regions around the world (Zhang et al. 2010) and is widely known to cause problems with floating plants (Villamagna and Murphy 2010). According to its extensive root system, the water hyacinth root can consume large amounts of chemical pollutants in the water (Malik 2007). Therefore, it has the ability to rapidly cover a pond surface. In fact, its growth can double in 6 to 28 days and weigh up to 270 to $400 \mathrm{t}$ per hectare (Epstein 1998; Malik 2007). On the other hand, water hyacinth roots contain high cellulose polymer that could be used to produce cellulose membranes (Istirokhatun et al. 2015) and cellulose nanofibers (Sundari and Ramesh 2012) as a cheap material. A benefit of this method is the use of the normal gracility of a root to absorb an essential oil from the outside 
to the inside of the root cells without using an instrument such as a low pressure pump and to hold the release of bergamot oil for a long term. In addition, during the drying phase at room temperature, the root cells could prevent the evaporation of essential oil from the inside of the cells.

Bergamot oil is one of the essential oils that come from citrus fruits. Limonene (32-70\% of the whole oil) is found to be one of the main components of bergamot oil (SánchezGonzález et al. 2011a, b; Russo et al. 2013). Many reports confirmed that good antimicrobial properties are found in essential oil and could be used to control molds (Matan and Matan 2008; Mohammadi et al. 2015) and insects (Harish et al. 2014; Pandey et al. 2014). However, limited number of research article has been investigated the antifungal activity of bergamot oil in vapor phase. In addition, a problem with using bergamot oil is easy to become volatile into the air within a short period of time. While, the germicidal effect of UV-C light has been acknowledged for more than a century (Guerrero-Beltran and Barbosa-Canovas 2004; Pinheiro et al. 2015), only a few reports have been conducted on the enhanced antifungal activity of absorbent material made from the water hyacinth root containing bergamot oil by UV-C; therefore, the purpose of this study is to investigate the possibility of using a water hyacinth root to absorb bergamot oil in water and then using UV-C to enhance the antifungal activity of bergamot oil in absorbent material for inhibiting surface mold of brown rice.

\section{Materials and methods}

\section{Culture}

A strain of mold (Aspergillus flavus WU1511) was isolated from the surface of brown rice. Codes refer to the strain held in the culture collection of the Innovation of Essential Oil for Food Safety and Packaging Laboratory of Walailak University in Nakhon Si Thammarat. Spores of tested mold were grown on a malt extract agar (Merck Ltd, Thailand) at $25^{\circ} \mathrm{C}$ for $72 \mathrm{~h}$ and then were suspended by $9 \mathrm{ml}$ of deionized water. Thereafter the spores were counted by using a haemocytometer and the suspension was adjusted to a concentration of $10^{6}$ spores $\mathrm{ml}^{-1}$ by dilution with sterile distilled water before use. The viability of all strains was checked by using quantitative colony counts at $10^{6} \mathrm{cfu} \mathrm{ml}^{-1}$.

\section{Bergamot oil and limonene}

The bergamot oil, derived by steam distillation, was provided by the Thai China Flavors \& Fragrances Industry Co. (Thailand). Limonene was purchased from Sigma Aldrich (Germany).

\section{Brown rice}

Brown rice was prepared from Khai Mod Rin (NSRC9500113) unhusked rice, local rice grown in the Nakhon Si Thammarat province, Thailand. The rice was obtained from the Nakhon Si Thammarat Rice Research Center. It was harvested in February 2015. After the harvest, the unhusked rice was air-dried to reduce moisture content to $\sim 12 \%$. Husk of the grains were removed mechanically. Whole grain brown rice was then vacuum-packed and stored at $4{ }^{\circ} \mathrm{C}$ before using.

\section{Effect of UV-C radiation and essential oil released from a water hyacinth root absorbent on agar}

The water hyacinth plants, naturally grown in a local pond $\left(\sim 28{ }^{\circ} \mathrm{C}\right)$ in Walailak University, Nakhon Si Thammarat, Thailand, were collected. All of the leaves with a size of $\sim 35 \mathrm{~cm}$ in diameter and $50 \mathrm{~cm}$ high) and roots (with a size of $\sim 6 \mathrm{~cm}$ wide $\times 0.2 \mathrm{~cm}$ thick $\times 18 \mathrm{~cm}$ long) of $75 \pm 5 \mathrm{~g}$ was prepared for each treatment. The whole plants were washed eight times by dipping into deionised water $(500 \mathrm{ml})$ at $6 \mathrm{~h}$ interval for up to $48 \mathrm{~h}$. Bergamot oil and limonene at concentration of $300 \mu \mathrm{ml}^{-1}$ was prepared by using deionized water. The solution was amended with $0.2 \%$ of linear alkyl benzene sulfonate (Sherwood Chemicals PCL, Thailand) as a surfactant. Root sections of the living plants were then submerged in the solution $(500 \mathrm{ml})$ for $20 \mathrm{~min}$ at $30{ }^{\circ} \mathrm{C}$. Then, they were placed in a round stainless plate $(\phi \sim 20 \mathrm{~mm})$. Next, heating at $50{ }^{\circ} \mathrm{C}$ for about $10 \mathrm{~min}$ was used to reduce total weight of roots containing the essential oil solution from $75 \pm 5 \mathrm{~g}$ to $10 \pm 5 \mathrm{~g}$. An absorbent material $(20 \mathrm{~mm}$ diameter and $3 \mathrm{~mm}$ long) was prepared by compressing a round disc of dried root $(10 \pm 5 \mathrm{~g})$ in a stainless tube $(\phi \sim 20 \mathrm{~mm})$. All absorbent materials were then stored under controlled humidity of $65 \%$ (Sanplatec Corp, Japan) for $24 \mathrm{~h}$ before testing. The roots with palm oil (Morakot Industries PCL., Thailand) within the same conditions were used as control.

Malt extract agar (MEA) plates (Merck Ltd, Thailand) were inoculated with $0.1 \mathrm{ml}$ of spore suspension $\left(10^{1}-10^{6}\right.$ spores $\mathrm{ml}^{-1}$ ) spread evenly on the agar surface. Two groups of MEA were divided. For the first group, the absorbent from bergamot and limonene were placed into the Petri dish lid. Round disc absorbent from vegetable oil was used for a second group (control). Then, all absorbents were irradiated with UV-C ( $\lambda=253.7 \mathrm{~nm}$, Phillips UV-C $30 \mathrm{~W}$ lamp, Phillips, Thailand) in the biological safety cabinet (Cellgard, USA) for $10 \mathrm{~min}$. Control treatments were done using bergamot oil without UV$\mathrm{C}$, and only UV-C radiation without bergamot oil. After closing, all plates were kept at $25^{\circ} \mathrm{C}$ for $72 \mathrm{~h}$ in a controlled incubator (Binder, Germany). The colony count of $A$. flavus 
in the MEA was estimated. The percent inhibition of spore germination was computed by the following Eq. 1:

$\operatorname{Inhibition}(\%) \equiv \frac{N_{c}-N_{s}}{N_{c}} \times 100$

Where $\mathrm{Nc}$ is the colony count number $\left(\log _{10} \mathrm{cfu} \mathrm{ml}^{-1}\right)$ in the control and Ns is the number of the colony count $\left(\log _{10} \mathrm{cfu}\right.$ $\mathrm{ml}^{-1}$ ) in the sample. Three replications were performed for each treatment.

\section{Optimization by response surface methodology on brown rice inoculated with $A$. flavus}

Production process optimization of absorbent material from water hyacinth root was carried out in the same way as in "Effect of UV-C radiation and essential oil released from a water hyacinth root absorbent on agar". Various concentrations of bergamot oil $\left(300,500\right.$ and $\left.700 \mu \mathrm{ml}^{-1}\right)$ and heating temperatures $\left(50,70\right.$ and $\left.90{ }^{\circ} \mathrm{C}\right)$ were employed. The roots containing the bergamot oil $(75 \pm 5 \mathrm{~g})$ were heated for $10 \mathrm{~min}$ until a final weight of $10 \pm 5 \mathrm{~g}$ was obtained. After compressing dried root $(10 \pm 5 \mathrm{~g})$ in a stainless tube into a round disc ( $20 \mathrm{~mm}$ diameter and $3 \mathrm{~mm}$ long), the absorbent materials obtained were then irradiated with UV-C for 10, 15, and $20 \mathrm{~min}$. The roots with palm oil and UV-C in the same treatment conditions, bergamot oil without UV-C, limonene without UV-C, and UV-C radiation for 10, 15, 20 min without essential oil were used as control.

Brown rice ( $25 \mathrm{~g})$ was added into a sterilization Petri dish. Then, A. flavus (1 ml) was inoculated on the surface of brown rice. The rice was put into a biological safety cabinet (Cellgard, NuAire, USA) to be dried for 10 min Mold spore were allowed to attach to brown rice for $90 \mathrm{~min}$. Next, the absorbent from each of the round disc $(\phi \sim 20 \mathrm{~mm})$ was placed into the Petri dish lid. After the plate was closed, all plates were stored at $25^{\circ} \mathrm{C}$ for 10 days. For mold count, the brown rice samples were placed into sterile stomacher bags with $225 \mathrm{ml}$ of buffered peptone water (BPW; Nissui Pharmaceutical CO., LTD, Tokyo, Japan). Then, each count of the A. flavus was done by using MEA to count the colonies (Suhem et al. 2013).

A second order polynomial quadratic equation was fitted to the data to relate the mold count ( $\left.\mathrm{cuf} \mathrm{g}^{-1}\right)(\mathrm{Y})$ to the concentration of bergamot oil $\left(\mathrm{X}_{1}\right)$, UV-C exposure time $\left(\mathrm{X}_{2}\right)$ and drying temperature $\left(\mathrm{X}_{3}\right)$. The model equation (Eq. 2) for a 3factor system is:

$$
\begin{aligned}
Y= & b_{0}+b_{1} X_{1}+b_{2} X_{2}+b_{3} X_{3}+b_{11} X_{1}^{2}+b_{22} X_{2}^{2} \\
& +b_{33} X_{3}^{2}+b_{12} X_{1} X_{2}+b_{13} X_{1} X_{3}+b_{23} X_{2} X_{3}
\end{aligned}
$$

Where $\mathrm{Y}$ is the predicted response, $\mathrm{b}_{0}$ is the intercept, $\mathrm{b}_{1}, \mathrm{~b}_{2}$ and $b_{3}$ are the linear coefficients, $b_{11}, b_{22}$, and $b_{33}$ are the squared coefficients, $b_{12}, b_{13}$ and $b_{23}$ are the interaction coefficients, and $X_{1}, X_{2}$ and $X_{3}$ are the independent variables used in this study. The quality of fit was checked with the coefficient of determination $R^{2}$ and its statistical significance was determined by the $F$-test. The statistical analysis was performed by using Statistica software (StatSoft, USA).

\section{Shelf-life extension of brown rice}

Brown rice (25 g) was added into a sterilized Petri dish. The samples of round plate absorbent $(\phi \sim 20 \mathrm{~mm})$ prepared from bergamot oil at $500 \mu \mathrm{l} \mathrm{ml}^{-1}$, limonene at $400 \mu \mathrm{ml}^{-1}$ and drying temperature at $70{ }^{\circ} \mathrm{C}$ with $\mathrm{UV}$ radiation time of 15 min were placed into a Petri dish. Plates were kept at $25^{\circ} \mathrm{C}$ and $100 \% \mathrm{RH}$ for 12 weeks. The control was done with vegetable oil absorbent. Each treatment was replicated five times. Following incubation, the brown rice was individually rated for mold growth on a scale of 0 to 5 , with 0 denoting clean specimens and 5 representing heavy mold growth $(0=$ clean, $1=20 \%, 2=40 \%, 3=60 \%, 4=80 \%$ and $5=100 \%$ of mold growth) (Modified from Nonthakaew et al. 2015).

\section{Optical microscopy}

Morphology of the water hyacinth plant root both with and without bergamot oil was observed by using a stereo microscope (Olympus SZ-CTV microscope, Japan) with a video camera (Olympus DP12, Japan). In addition spore germination of A. flavus with and without limonene vapor at $400 \mu \mathrm{l} \mathrm{ml}^{-1}$ after UV-C radiation on MEA for $72 \mathrm{~h}$ was observed by the compound microscope (Olympus CH30, Japan).

\section{Fourier transform infrared spectroscopy (FTIR)}

The dried absorbent prepared from bergamot oil at $500 \mu \mathrm{ml}^{-1}$ with UV-C exposure time for $15 \mathrm{~min}$ and drying temperature at $70^{\circ} \mathrm{C}$ and the control (without bergamot oil) as well as bergamot oil and limonene were scanned after UV radiation for $15 \mathrm{~min}$ in a Perkin-Elmer model Spectrum One FTIR spectrometer (Perkin Elmer, USA). Also, the horizontal attenuated total reflectance accessory (HATR) was mounted into the sample compartment. The internal reflection crystal, which was made of zinc selenide, had a $45^{\circ}$ angle of incidence to the IR beam. Spectra were acquired at a resolution of $4 \mathrm{~cm}^{-1}$ and the measurement range was from 4000 $600 \mathrm{~cm}^{-1}$ (mid-IR region) at room temperature. Automatic signals were collected in 16 scans at a resolution of $4 \mathrm{~cm}^{-1}$ and were normalized against a background spectrum recorded from the clean, empty cell at $25^{\circ} \mathrm{C}$. Analysis of spectral data was carried out by using the Spectrum One software program. A change in the chemical composition of each sample was observed (Suhem et al. 2015). 


\section{Results and discussion}

\section{Effect of UV-C radiation and bergamot oil vapor on MEA}

The effects of UV-C and bergamot oil vapor on the spore germination of A. flavus on MEA is presented in Fig. 1. Using UV-C for 10 min exposed to surface of a water hyacinth root absorbent containing bergamot oil or limonene exhibited a significant reduction of spore germination at an inhibition of 26 and $35 \%$ respectively. Spore germination was inhibited by 3 and $8 \%$ respectively when without UV-C. No inhibition was found when using UV-C alone for $10 \mathrm{~min}$.

Although, inhibitory effects of UV-C against different mold have previously been reported (Guerrero-Beltran and Barbosa-Canovas 2004; Pinheiro et al. 2015), UV-C radiation for $10 \mathrm{~min}$ was shown to be less effective to reduce spore germination of $A$. flavus in this experiment. Nevertheless, Osman et al. (1989) explained that the inhibitory effect on mold germination was dependent on the exposure period and maximum inhibition was obtained after UV irradiation for $4 \mathrm{~h}$. Therefore, higher exposure time was required to reduce mold growth in an optimization section. Reason on the enhancing antifungal of bergamot oil vapor using UV-C has been explained in possible mode of action section.

\section{Optimization of absorbent material on the growth of $A$.flavus in brown rice}

Box-Behnken Design (BBD) was applied in the response surface methodology (RSM). The three independent variables $\left(\mathrm{X}_{1}, \mathrm{X}_{2}, \mathrm{X}_{3}\right)$ and the dependent variables (Mold count ( $\mathrm{cfu} \mathrm{g}^{-1}$ ) were optimized by the experimental plan. A set of 45 experiments were carried out. The measurement of each response variable was reported as the average of 3 replicates (Tables 1 and 2). The results of Box-Behnken Design experiments to determine the effects of the concentration of bergamot oil $\left(\mathrm{X}_{1}\right)$, UV-C exposure time $\left(\mathrm{X}_{2}\right)$ and drying

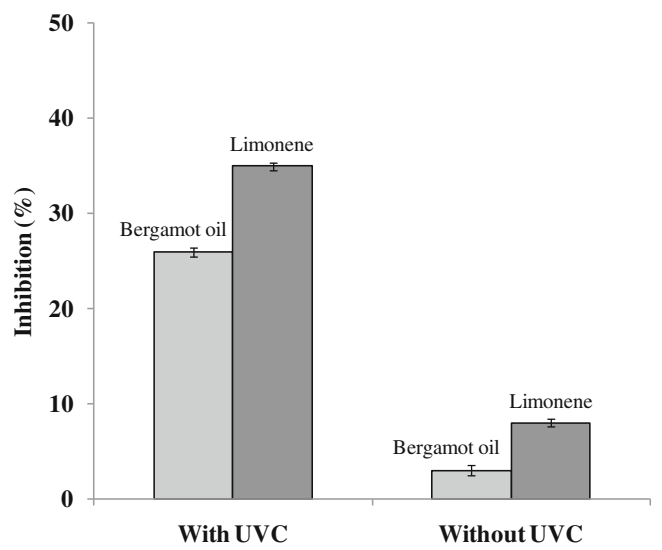

Fig. 1 Effect of UV-C and bergamot oil and limonene on a spore germination of Aspergillus flavus on MEA
Table 1 Maximum and minimum levels of variables used in Box-Behnken design

\begin{tabular}{lllll}
\hline \multirow{2}{*}{ Factor } & Parameters & \multicolumn{3}{l}{$\begin{array}{l}\text { Actual levels of code } \\
\text { factors }\end{array}$} \\
\cline { 3 - 5 } & & -1 & 0 & 1 \\
\cline { 3 - 5 } & & & & \\
\hline $\mathrm{X} 1$ & Concentration of bergamot oil $\left(\mu \mathrm{ml}^{-1}\right)$ & 300 & 500 & 700 \\
$\mathrm{X} 2$ & UVC exposure time $(\mathrm{min})$ & 10 & 15 & 20 \\
$\mathrm{X} 3$ & Drying temperature $\left({ }^{\circ} \mathrm{C}\right)$ & 50 & 70 & 90 \\
\hline
\end{tabular}

temperature $\left(\mathrm{X}_{3}\right)$ are shown in Table 2. Furthermore, the response surface plots and contour plots are displayed in Fig. 2a and $b$. Figure 2 suggested that the optimum points for producing absorbent material from a water hyacinth root were within the design limits. All surface and contour plots showed that at the level of the central factors (bergamot oil at $500 \mu \mathrm{ml}^{-1}$, UV-C exposure time for $15 \mathrm{~min}$ and drying time at $70^{\circ} \mathrm{C}$ ), no growth of A. flavus was detected after placing the absorbent on the cover. Higher concentrations of bergamot oil $\left(700 \mu \mathrm{ml}^{-1}\right)$ with the same temperature $\left(70^{\circ} \mathrm{C}\right)$ also showed no growth of A. flavus on the brown rice. Using a lower temperature $\left(50^{\circ}\right.$ C) or a higher temperature $\left(90^{\circ} \mathrm{C}\right)$ found a higher amount of A. flavus on brown rice. Therefore, the concentration of bergamot oil and the drying temperature were found to be significant main factors. On the other hand, the maximum number of mold growth $\left(\sim 6 \log _{10} \mathrm{cfu} \mathrm{g}^{-1}\right)$ in the control (vegetable oil in the same treatment condition, bergamot oil without UV-C, limonene without UV-C radiation, and UV-C radiation for 10 20 munities) were obtained in 10 days. Results clearly show

Table 2 Box-Behnken experimental design matrix with experimental values of mold count (cuf g ${ }^{-1}$ )

\begin{tabular}{|c|c|c|c|c|c|c|c|}
\hline \multirow[t]{2}{*}{ NO. } & \multicolumn{3}{|c|}{ Code } & \multicolumn{3}{|c|}{ Un code } & \multirow{2}{*}{$\begin{array}{l}\text { Mold count } \\
\mathrm{Y}\left(\operatorname{cuf~}^{-1}\right)\end{array}$} \\
\hline & $\mathrm{X}_{1}$ & $\mathrm{X}_{2}$ & $\mathrm{X}_{3}$ & $\mathrm{X}_{1}$ & $\mathrm{X}_{2}$ & $\mathrm{X}_{3}$ & \\
\hline 1 & -1 & -1 & 0 & 300 & 10 & 70 & 5.2 \\
\hline 2 & 1 & -1 & 0 & 700 & 10 & 70 & 0.0 \\
\hline 3 & -1 & 1 & 0 & 300 & 20 & 70 & 5.4 \\
\hline 4 & 1 & 1 & 0 & 700 & 20 & 70 & 0.0 \\
\hline 5 & -1 & 0 & -1 & 300 & 15 & 50 & 5.8 \\
\hline 6 & 1 & 0 & -1 & 700 & 15 & 50 & 3.7 \\
\hline 7 & -1 & 0 & 1 & 300 & 15 & 90 & 5.5 \\
\hline 8 & 1 & 0 & 1 & 700 & 15 & 90 & 3.5 \\
\hline 9 & 0 & -1 & -1 & 500 & 10 & 50 & 4.7 \\
\hline 10 & 0 & 1 & -1 & 500 & 20 & 50 & 4.2 \\
\hline 11 & 0 & -1 & 1 & 500 & 10 & 90 & 3.5 \\
\hline 12 & 0 & 1 & 1 & 500 & 20 & 90 & 2.2 \\
\hline 13 & 0 & 0 & 0 & 500 & 15 & 70 & 0.0 \\
\hline 14 & 0 & 0 & 0 & 500 & 15 & 70 & 0.0 \\
\hline 15 & 0 & 0 & 0 & 500 & 15 & 70 & 0.0 \\
\hline
\end{tabular}




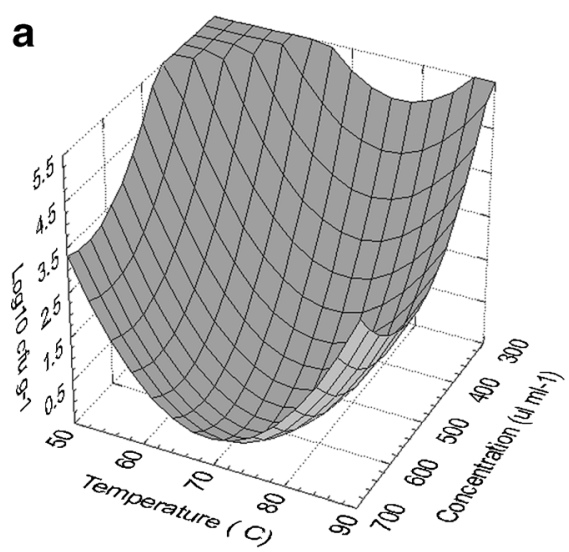

b

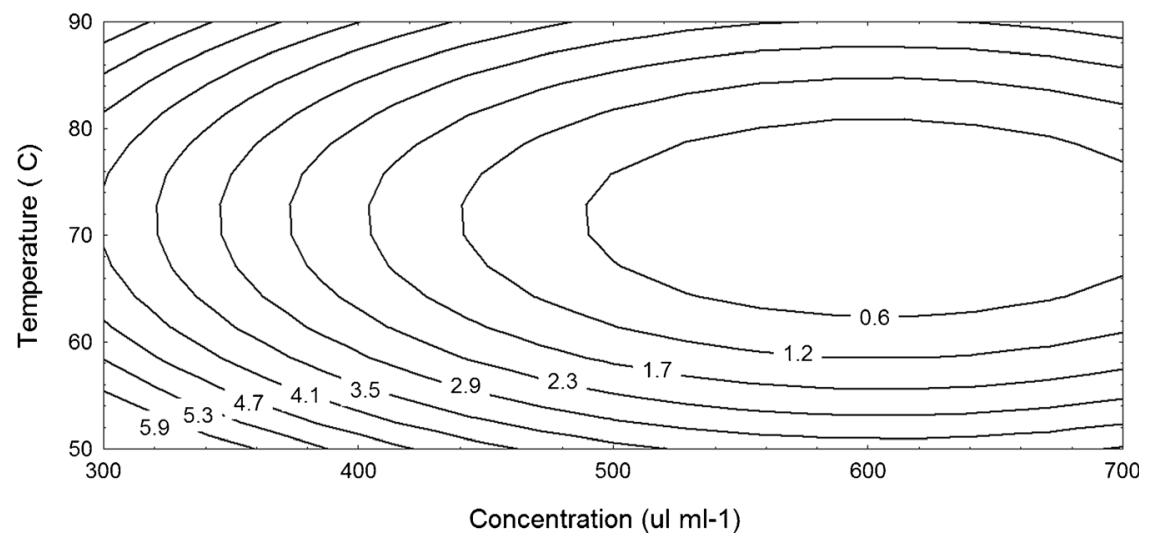

Fig. 2 Response surface plots (a) and contour plots (b) showing the effect of concentration of bergamot oil and drying temperature on growth of $A$. flavus on brown rice

that UV-C radiation had an effect on improving the antifungal activity of bergamot oil and limonene. Therefore, by using the bergamot oil absorbent material under optimum conditions with UV-C, the number of mold in brown rice could be reduced to zero (not found). The coefficients of the regression equation obtained after ANOVA for mold count are presented in Table 3. Mold count on brown rice is best predicted by the model Eq. 3;

$$
\begin{aligned}
Y= & 57.87500-0.05419 X_{1}-0.98063 X_{3}+0.00004 X_{1}^{2} \\
& +0.00703 X_{3}^{3}
\end{aligned}
$$

Where $\mathrm{Y}$ predicted mold count, $\left(\mathrm{X}_{1}\right)$ concentration of bergamot oil and $\mathrm{X}_{3}$ drying temperature

The coefficient of determination $\left(\mathrm{R}^{2}\right)$ was 0.91 , which indicated that the model equations adequately fit the data. Magnitudes of the model coefficients showed that the concentration of bergamot oil $\left(\mathrm{X}_{1}\right)$ and drying temperature $\left(\mathrm{X}_{3}\right)$ had

Table 3 Analysis of variance (ANOVA) for response quadratic model from experimental designs

\begin{tabular}{lll}
\hline & $\begin{array}{l}\text { Degree } \\
\text { of freedom }\end{array}$ & Prob. $>F$ \\
\hline $\mathrm{X}_{1}$ & 1 & $0.04^{*}$ \\
$\mathrm{X}_{2}$ & 1 & 0.36 \\
$\mathrm{X}_{3}$ & 1 & $0.00^{*}$ \\
$\mathrm{X}_{1} * \mathrm{X}_{1}$ & 1 & $0.02^{*}$ \\
$\mathrm{X}_{1} * \mathrm{X}_{2}$ & 1 & 0.93 \\
$\mathrm{X}_{1} * \mathrm{X}_{3}$ & 1 & 0.96 \\
$\mathrm{X}_{2} * \mathrm{X}_{2}$ & 1 & 0.22 \\
$\mathrm{X}_{2} * \mathrm{X}_{3}$ & 1 & 0.74 \\
$\mathrm{X}_{3} * \mathrm{X}_{3}$ & 1 & $0.00^{*}$ \\
\hline
\end{tabular}

$*(p<0.05)$ significant impacts on growth of $A$. flavus on brown rice. UVC exposure time $\left(\mathrm{X}_{2}\right)$ had a higher $\mathrm{p}$ value $(p>0.05)$ and was statistically insignificant. Therefore, bergamot oil and UV-C exposure time from 10 to $20 \mathrm{~min}$ could be used to reduce the number of mold growth.

The effects of mild heat $\left(60-70{ }^{\circ} \mathrm{C}\right)$ on the volatile composition of essential oil was reported by Matan et al. (2013) and Olmedo et al. (2015). Results showed an increase of some main components after thermal study. For example, carvacrol increased from 20.4 to $26.4 \%$ and cymene increased from 1.94 to $13.13 \%$ during a thermal stability study (Olmedo et al. 2015). In 2013, Matan et al. reported that using lime oil at $90 \mu \mathrm{ml}^{-1}$ with heat curing at $70{ }^{\circ} \mathrm{C}$ showed the best enhanced antifungal activity of lime oil against $A$. niger in both the medium and on the sedge. However, in 2007 Yang et al. showed that when water temperature was increased by more than $100^{\circ} \mathrm{C}$, the degradation of terpenes ( $\alpha$-pinene, limonene, camphor, citronellol, and carvacrol) became more serious due to poorer terpene. Therefore, results from this experiment show that the use of mild heat $\left(70^{\circ} \mathrm{C}\right)$ showed stronger properties of bergamot oil after UV-C radiation against $A$. flavus on brown rice than by using a higher temperature $\left(90^{\circ} \mathrm{C}\right)$ due to their main components temperature sensitivity, especially limonene. For the effect of essential oil concentration, a higher concentration of bergamot oil was needed ( $\geq 500 \mathrm{ul} \mathrm{ml}^{-1}$ ) when in the essential oil gas phase against molds. In addition, when the root was dried at mild temperature it was confirmed that water could be released from the inside of the root to the air quickly (within $10 \mathrm{~min}$ ) while the root cell can catch essential oil both during and after drying. This result is close agreement with Sánchez-González et al. (2011a, b) who reported that limonene release could be improved by promoting higher water content; the active compounds will be released very slowly due to the enhancement of 
the film hydration rate during drying. The use of essential oil in a root has more application advantages because it could be applied in the long-term use of controlled release. From this process, the water hyacinth could be converted into a valuable absorbent material for use in food and agricultural products.

\section{Shelf-life extension of brown rice}

Natural mold resistance levels of the treated brown rice and control were found to be significantly different (Fig. 3). The results are calculated as the average ratings of five brown rice plates $(n=5)$. Normally, oily treatment might have some effects on moisture exclusion from the test specimens (Matan et al. 2014) but the controls (treated with vegetable oil) found a value of $100 \%$ mold coverage within 4 weeks. On the other hand, vapor from the absorbent containing bergamot oil at $500 \mu \mathrm{ml}^{-1}$ and limonene vapor at $400 \mu \mathrm{l} \mathrm{ml}^{-1}$ were capable of inhibiting natural molds for at least 12 weeks. Indeed, limonene (found $\sim 79 \%$ in bergamot oil or $\sim 400 \mu \mathrm{ml}^{-1}$ in $500 \mu \mathrm{ml}^{-1}$ of bergamot) has been shown to be a major antifungal constituent in bergamot oil after UV-C against $A$. flavus on brown rice. Therefore, a developed absorbent could extend the shelf-life of brown rice by at least 2 times that of the control.

\section{Morphology of the water hyacinth root and FTIR analysis}

Morphology of the water hyacinth root both with and without bergamot oil-water solution oil at $500 \mu \mathrm{lml}^{-1}$ is shown in Fig. 4 (a-d). From Fig. 4 it can be observed that a water hyacinth root could absorb water (Fig. 4a, c) and also water with bergamot oil (Fig. 2b, d) within $20 \mathrm{~min}$. After bergamot oil adsorption to root cells, a dark brown color inside the layers of root tissue was found. Therefore, this experiment showed that water hyacinth roots could absorb essential oil in water. In addition, after complete diffusion, the changed color around the root

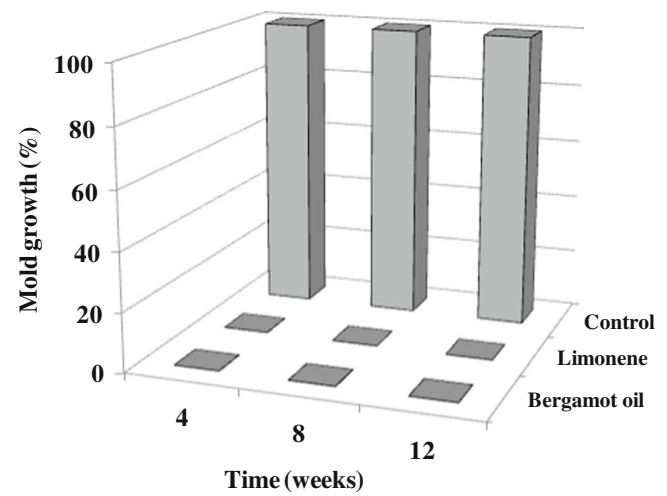

Fig. 3 Effect of bergamot oil at $500 \mu \mathrm{ml}^{-1}$ and limonene at $400 \mu \mathrm{ml}^{-1}$ on naturally infected brown rice during storage for 12 weeks could be observed and easy to detect by the human eye. In 1995, Low et al. reported that water hyacinth roots could represent a cheap source of biosorbent for basic dyes with maximum sorption capacities of water hyacinth roots for methylene blue and victoria blue of 128.9 and $145.4 \mathrm{mg} \mathrm{g}^{-1}$, respectively. In addition, a water hyacinth can cause a change in water clarity, decreasing turbidity and other pollutants in the water (Delgado et al. 1993; Nguyen et al. 2015). Results from this experiment indicated that the water hyacinth root plays an outstanding role in absorbing an oil in water solution and for its role as a pollutant from oil releasing oil from the environment.

For FTIR spectrum, the control (without essential oil) showed a characteristic absorption of around 2900$3400 \mathrm{~cm}^{-1}$, attributed to the $\mathrm{OH}$ and $\mathrm{CH}$ group. The bands at 1360 to $1460 \mathrm{~cm}^{-1}$ were associated with $\mathrm{C}-\mathrm{H}$ deformation in lignin, cellulose and hemicelluloses groups (Kartal et al. 2013). Bands in the $900-1180 \mathrm{~cm}^{-1}$ region were associated with $\mathrm{C}-\mathrm{O}-\mathrm{C}$ stretching and $\mathrm{C}-\mathrm{O}$ ester bond stretching (the structure of glycosidic linkage) of cellulose, hemicelluloses and lignin groups (Cao and Tan 2004). For water hyacinth roots containing bergamot oil or limonene, higher changes in the $2900 \mathrm{~cm}^{-1}$ region (change of $\mathrm{CH}$ group) were found. On top of that, a pattern of spectra in the 900-1180 range were observed due to the change in the $\mathrm{C}-\mathrm{O}-\mathrm{C}$ stretching and $\mathrm{C}-\mathrm{O}$ ester bonds. In addition, the peak pattern of bergamot oil was found similarly to the limonene after UV-C radiation.

\section{Possible mode of action}

Since FTIR peaks of bergamot oil derivatives and limonene were observed in absorbent material after drying at $70{ }^{\circ} \mathrm{C}$ and UV-C radiation for $15 \mathrm{~min}$, it is possible that mild heat could induce limonene and other derivatives in bergamot oil to diffuse into the absorbent material. Higher amount of volatile compounds absorbed could later show good antifungal activities and could be activated by UV-C to prolong releasing time of these volatile compounds out of the absorbent material. Vapor of limonene at $400 \mu \mathrm{l} \mathrm{ml}{ }^{-1}$ after UV-C radiation was able to prevent spore germination of A. flavus (Fig. 5b, d) on MEA for up to $72 \mathrm{~h}$. In the control treatments with limonene but without UV-C, spores of $A$. flavus were observed to start to germinate on MEA just after $12 \mathrm{~h}$ and later fully germinate after 72 h (Fig. 5a, c). Although Aspergillus have been used successfully in many bioconversion reactions (Demyttenaere et al. 2000), but A. flavus was not able to convert limonene to other compounds such as $\alpha$-terpineol (Demyttenaere et al. 2001). Furthermore, vapor of limonene on brown rice was still observed for up to 12 weeks. It might be possible that limonene after UV-C radiation could affect some enzymes involving in spore 
Fig. 4 A longitudinal-section and a cross-section of the water hyacinth root after immersion into the water $(\mathbf{a}, \mathbf{c})$ and water with bergamot oil at $500 \mu \mathrm{ml}^{-1}(\mathbf{b}, \mathbf{d})$ for $20 \mathrm{~min}$

Fig. 5 Spore germination of A.flavus with vapor of limonene at $400 \mu \mathrm{l} \mathrm{ml} l^{-1}$ without UVC radiation on MEA for $12 \mathrm{~h}$ (a) and $72 \mathrm{~h} \mathrm{(c)} \mathrm{and} \mathrm{after} \mathrm{UVC} \mathrm{radiation}$ for $12 \mathrm{~h}(\mathbf{b})$, and $72 \mathrm{~h}(\mathbf{d})$
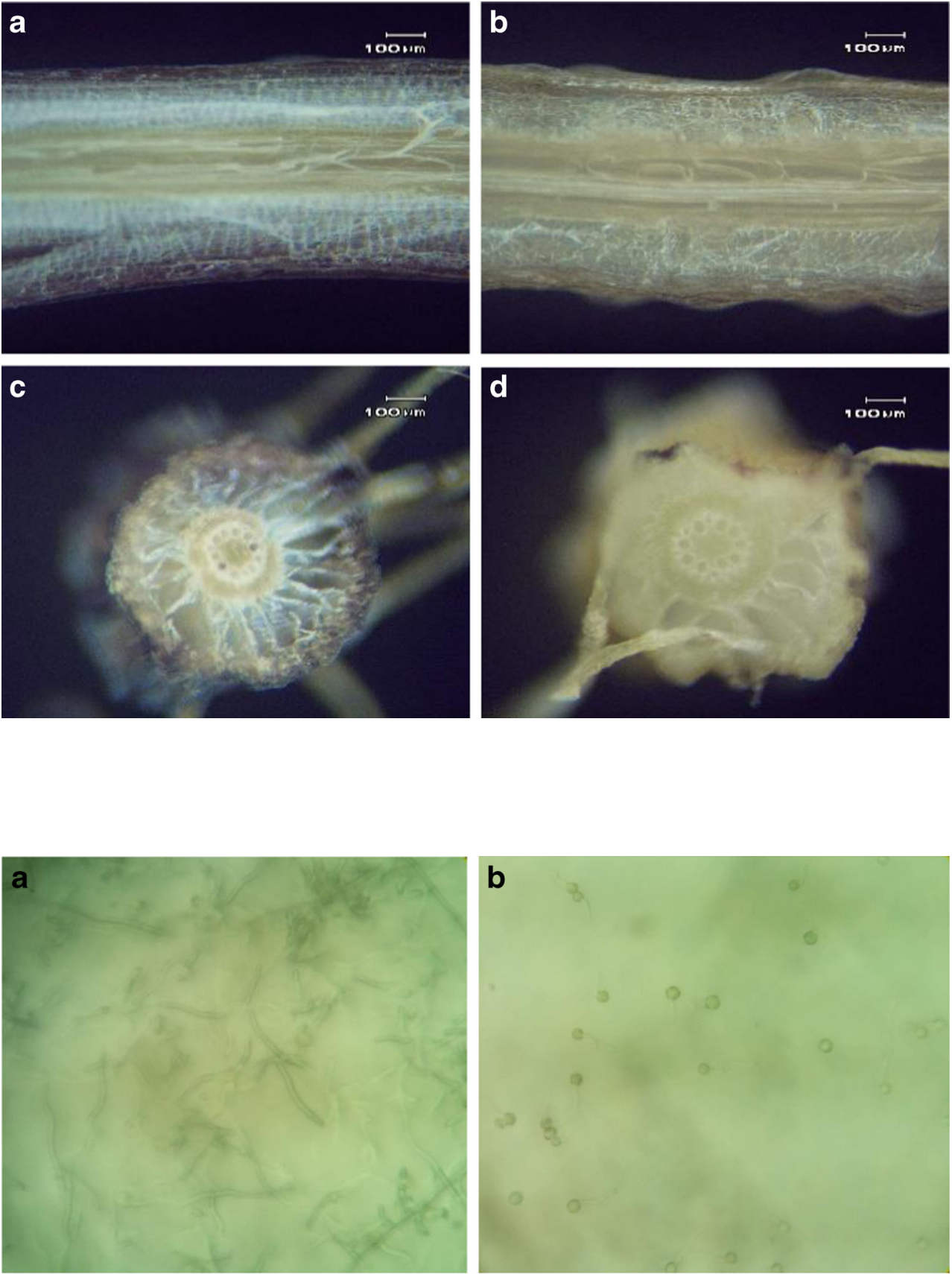

b

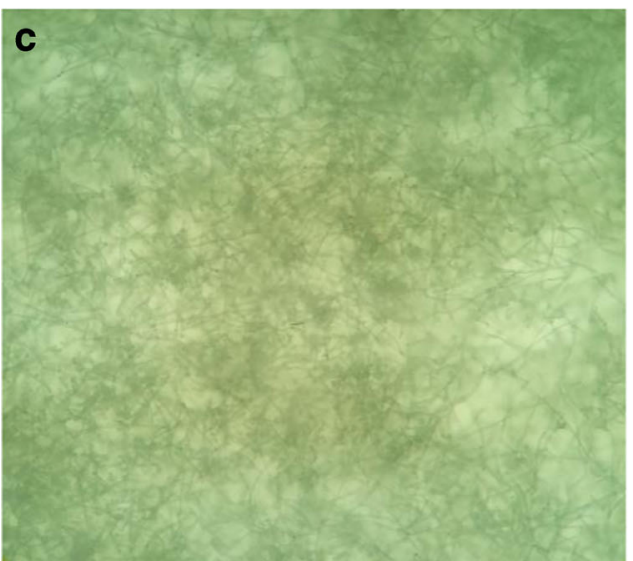

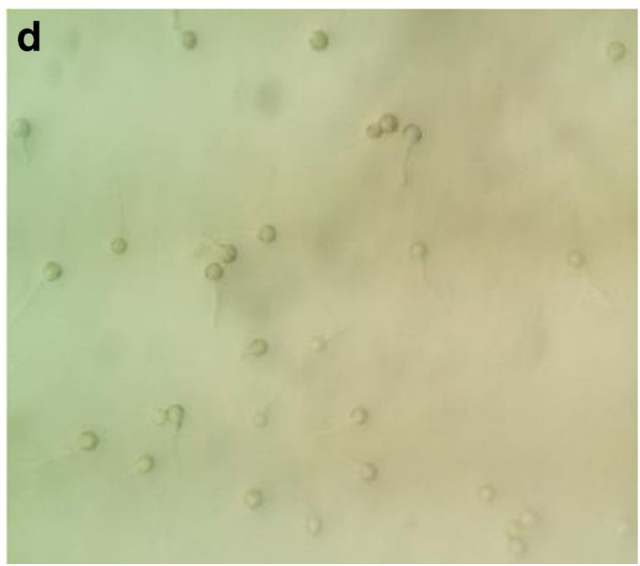


germination causing an extension of the lag phase of spore germination. Future work should be performed to elucidate this claim.

\section{Conclusions}

Within this work, a new and cheap process to produce essential oil absorbent by simply dipping the living water hyacinth plants in a solution of essential oil in water was developed. Heat curing and UV-C was used to enhance antifungal activity of the essential oil and to reduce moisture from the root cell. The antifungal absorbent material was produced by immersion the water hyacinth plant into the solution of bergamot oil (500-700 $\mu \mathrm{l} \mathrm{ml}^{-1}$ in water) for $20 \mathrm{~min}$. Separated root sections were then heated at $70{ }^{\circ} \mathrm{C}$ for $10 \mathrm{~min}$. The round disc of absorbent material was produced from the dried roots before being exposed with UV-C for $15 \mathrm{~min}$. Limonene in bergamot oil was proposed to be responsible for temperature dependencies of the essential oil antifungal activities observed. Furthermore, the UV-C could be used to prolong releasing time of these volatile compounds out of the absorbent material. The produced absorbent was able to extend shelf-life of brown rice by twice of the control against $A$. flavus. The information obtained from this study may be useful to the rice industry for a protection of rice from harmful mold growth.

Acknowledgments This study was supported by the Thailand Research Fund (TRF) through the Royal Golden Jubilee Ph.D. Program (Grant. No. PHD/0090/2014), the Walailak University Fund, and the Office of the Higher Education Commission's Higher Education Research Promotion (HERP). The authors would like to thank Ms. Athiya Nonthakaew and Ms. Kitiya Suhem for their help on the FTIR experimental setup.

\section{References}

Cao Y, Tan H (2004) Structural characterization of cellulose with enzymatic treatment. J Mol Struct 705:189-193

Carvalho MO, Pires I, Barbosa A, Barros G, Riudavets J, Garcia AC, Brites C, Navarro S (2012) The use of modified atmospheres to control Sitophilus zeamais and Sitophilus oryzae on stored rice in Portugal. J Stored Prod Res 50:49-56

Choi S, Jun H, Bang J, Chung SH, Kim Y, Kim BS, Kim H, Beuchat LR, Ryu JH (2015) Behaviour of Aspergillus flavus and Fusarium graminearum on rice as affected by degree of milling, temperature, and relative humidity during storage. Food Microbiol 46:307-313

Delgado M, Bigeriego M, Guardiola E (1993) Uptake of Zn, Cr and Cd by water hyacinths. Water Res 27:269-272

Demyttenaere JCR, del Carmen Herrera M, De Kimpe N (2000) Biotransformation of geraniol, nerol and citral by sporulated surface cultures of Aspergillus niger and Penicillium sp. Phytochemistry 55: 363-373

Demyttenaere JCR, Belleghem KV, Kimpe ND (2001) Biotransformation of $(R)-(+)-$ and $(S)-(-)$-limonene by fungi and the use of solid phase microextraction for screening. Phytochemistry 57(2):199-208

Epstein P (1998) Weeds bring disease to the east African waterways. Lancet 351:577

Guerrero-Beltran JA, Barbosa-Canovas GV (2004) Review: advantages and limitations on processing foods by UV light. Food Sci Technol Int 10:137-147

Harish G, Nataraja MV, Holajjer P, Thirumalaisamy PP, Jadon KS, Savaliya SD, Gedia MV (2014) Efficacy and insecticidal properties of some essential oils against Caryedon serratus (Oliver)-a storage pest of groundnut. J Food Sci Technol 51:3505-3509

Istirokhatun T, Rokhati N, Rachmawaty R, Meriyani M, Priyanto S, Susanto H (2015) Cellulose isolation from tropical water hyacinth for membrane preparation. Procedia Environ Sci 23:274-281

Kartal SN, Aysal S, Terzi E, Yılgör N, Yoshimura T, Tsunoda K (2013) Wood and bamboo-PP composites: fungal and termite resistance, water absorption, and FT-IR analyses. Bioresources 8:1222-1244

Low KS, Lee CK, Tan KK (1995) Biosorption of basic dyes by water hyacinth roots. Bioresour Technol 52:79-83

Malik A (2007) Environmental challenge vis a vis opportunity: the case of water hyacinth. Environ Int 33:122-138

Matan N, Matan N (2008) Antifungal activities of anise oil, lime oil, and tangerine oil against molds on rubberwood (Hevea brasiliensis). Int Biodeterior Biodegrad 62:75-78

Matan N, Matan N, Ketsa S (2013) Enhanced inhibition of Aspergillus niger on sedge (Lepironia articulate) treated with heat-cured lime oil. J Appl Microbiol 115:376-378

Matan N, Nisoa M, Matan N (2014) Antibacterial activity of essential oils and their main components enhanced by atmospheric RF plasma. Food Control 39:97-99

Mohammadi A, Hashemi M, Hosseini SM (2015) The control of Botrytis fruit rot in strawberry using combined treatments of Chitosan with Zataria multiflora or Cinnamomum zeylanicum essential oil. J Food Sci Technol. doi:10.1007/s13197-015-1871-7

Nguyen THT, Boets P, Lock K, Ambarita MND, Forio MAE, Sasha P, Dominguez-Granda LE, Hoang THT, Everaert G, Goethals PLM (2015) Habitat suitability of the invasive water hyacinth and its relation to water quality and macroinvertebrate diversity in a tropical reservoir. Limnologica 52:67-74

Nonthakaew A, Matan N, Aewsiri T, Matan N (2015) Antifungal activity of crude extracts of coffee and spent coffee ground on areca palm leaf sheath (Areca catechu) based food packaging. Packag Technol Sci 28:633-645

Olmedo RH, Asensio CM, Grosso NR (2015) Thermal stability and antioxidant activity of essential oils from aromatic plants farmed in Argentina. Ind Crop Prod 69:21-28

Osman M, Elsayed MA, Mohamed YAH, Abo-Zeid AM (1989) Effect of ultraviolet irradiation on germination and growth in Aspergillus flavus and Penicillium notatum. Mycol Res 92:293-296

Pandey AK, Palni UT, Tripathi NN (2014) Repellent activity of some essential oils against two stored product beetles Callosobruchus chinensis L. and C. maculatus F. (Coleoptera: Bruchidae) with reference to Chenopodium ambrosioides L. oil for the safety of pigeon pea seeds. J Food Sci Technol 51:4066-4071

Pinheiro J, Alegria C, Abreu M, Gonçalves E, Silva CM (2015) Use of UV-C postharvest treatment for extending fresh whole tomato (Solanum lycopersicum, cv. Zinac) shelf-life. J Food Sci Technol 52:5066-5074

Russo R, Ciociaro A, Berliocchi L, Cassiano MGV, Rombolà L, Ragusa S, Bagetta G, Blandini F, Corasaniti MT (2013) Implication of limonene and linalyl acetate in cytotoxicity induced by bergamot essential oil in human neuroblastoma cells. Fitoterapia 89:48-57

Sánchez-González L, Cháfer M, González-Martínez C, Chiralt A, Desobry S (2011a) Study of the release of limonene present in 
chitosan films enriched with bergamot oil in food stimulants. J Food Eng 105:138-143

Sánchez-González L, Pastor C, Vargas M, Chiralt A, González-Martínez C, Cháfer M (2011b) Effect of hydroxypropylmethylcellulose and chitosan coatings with and without bergamot essential oil on quality and safety of cold-stored grapes. Postharvest Biol Tec 60:57-63

Suhem K, Matan N, Nisoa M, Matan N (2013) Inhibition of Aspergillus flavus on agar media and brown rice cereal bars using cold atmospheric plasma treatment. Int J Food Microbiol 161:107-111

Suhem K, Matan N, Nisoa M, Matan N (2015) Inhibition of Aspergillus flavus on agar media and brown rice cereal bars using cold atmospheric plasma treatment. Int J Food Microbiol 161:107-111
Sundari MT, Ramesh A (2012) Isolation and characterization of cellulose nanofibers from the aquatic weed water hyacinth - Eichhornia crassipes. Carbohydr Polym 87:1701-1705

Villamagna AM, Murphy BR (2010) Ecological and socio-economic impacts of invasive water hyacinth (Eichhornia crassipes): a review. Freshw Biol 55:282-298

Yang Y, Kayan B, Bozer N, Pate B, Baker C, Gizir AM (2007) Terpene degradation and extraction from basil and oregano leaves using subcritical water. J Chromatogr A 1152:262-267

Zhang YY, Zhang DY, Barrett SH (2010) Genetic uniformity characterizes the invasive spread of water hyacinth (Eichhornia crassipes), a clonal aquatic plant. Mol Ecol 19:1774-1786 